\title{
"A Black Sister to Massachusetts": Latin America and the Fugitive Democratic Ethos of Frederick Douglass
}

\author{
JULIET HOOKER The University of Texas at Austin
}

\begin{abstract}
$T$ The aim of this article is to read Frederick Douglass as a theorist of democracy. It explores the hemispheric dimensions of Douglass' political thought, especially in relation to multiracial democracy. Douglass is generally viewed as an African-American thinker primarily concerned with U.S. politics, and the transnational scope of his ideas is rarely acknowledged. Instead, this article traces the connections between Douglass' Caribbean interventions and his arguments about racial politics in the United States. It argues that Douglass not only found exemplars of black self-government and multiracial democracy in the Caribbean and Central America, he also sought to incorporate black and mixed-race Latin Americans in order to reshape the contours of the U.S. polity and challenge white supremacy. Viewed though a hemispheric lens Douglass is revealed as a radically democratic thinker whose ideas can be utilized to sketch a fugitive democratic ethos that contains important resources for contemporary democratic theory and comparative political theory.
\end{abstract}

$\mathbf{T}$ he transnational dimensions of Frederick Douglass' political thought have been neglected in prevailing interpretations of him as a thinker thoroughly focused on the U.S., a perception further buttressed by his categorization as part of the assimilationist strand within African-American philosophy (Boxill 1992-1993) and as an exponent of American liberalism (Buccola 2012; Krause 2002; Myers 2008; Turner 2012). In contrast, this article seeks to enlarge the conceptual terrain of Douglass scholarship by locating a more geographically capacious Douglass whose engagement with Latin America reveals an important hemispheric dimension to his political thought. It joins recent analyses by historians and literary critics that highlight the centrality of Douglass' engagement with the rest of the Americas to his political ideas (Levine 2008; Nwankwo 2005; Polyné 2010), but shifts the locus of attention to suggest that we read Douglass more expansively as a theorist of democracy. Viewed though a hemispheric lens Douglass is revealed as a radically democratic thinker whose ideas can be utilized to sketch a fugitive democratic ethos that contains important resources for contemporary democratic theory. Engaging with the hemispheric coordinates of Douglass' political reflections and investments and his support for a composite U.S. nationality via immigration during the 19th century can illuminate early 21 st century debates about race, shifting demographics, and the character of U.S. democracy.

Juliet Hooker is Associate Professor of Government and of African and African Diaspora Studies, The University of Texas at Austin, 158 W. 21st St. Stop A1800, Austin, TX 78712-1709 (juliethooker@ austin.utexas.edu)

The final version of this article benefitted significantly from the thoughtful comments and constructive feedback I received from three anonymous reviewers for the APSR. Research for this article was supported by a College Research Fellowship from the College of Liberal Arts at the University of Texas at Austin, and a Visiting Fellowship at the W. E. B. Du Bois Institute for African American Research at Harvard University. Early versions of the article were presented at the Faculty Seminar of the Warfield Center for African and African-American Studies at UT-Austin and the Western Political Science Association annual meeting.
This article traces the connections between Douglass' positions on black emigration and U.S. expansionism to the Caribbean and Central America and his conception of democracy. ${ }^{1}$ It suggests that the thread that unites Douglass' seemingly contradictory Caribbean interventions and his view of U.S. racial politics was his commitment to multiracial democracy. For Douglass, Latin America and the Caribbean functioned as both models of racial egalitarianism and participants in the project of reshaping the U.S. polity. ${ }^{2}$ Grappling with Douglass' writings on Latin America thus reveals a heretofore underappreciated element of his political thought: the articulation of a conception of democracy informed by black fugitivity that could enable the practice of egalitarian politics in multiracial polities. The question of the intellectual, moral, and civic capacities of nonwhites and the kinds of political relations that could be established between whites and nonwhites in the multiracial republics of the Americas were far from settled during the second half of the 19th century, as evidenced by the opposition of many white abolitionists in the U.S. to African-American social and political equality. It is in this context that Douglass articulates a distinctive conception of multiracial democracy, or the political coexistence on egalitarian terms of individuals of "all races and creeds" as fellow citizens. Unlike the myths of racial democracy formulated in Latin America during the 20th century, however, which conflate multiracial democracy and mestizaje, Douglass envisions a "composite nationality" anchored in the idea of a universal human right to

\footnotetext{
${ }^{1}$ I use the term "Latin America" to encompass Haiti and the Caribbean coast of Central America-despite the fact that their complex geopolitical histories and linguistic differences do not align with dominant ideas of the region as Spanish-speaking with an IndoHispanic cultural heritage-because Douglass' conception of the Americas corresponds to this expansive use of the term. See Mignolo (2006) on its origins and implications.

${ }^{2}$ Douglass and his African-American contemporaries undoubtedly overestimated Latin America's racial egalitarianism, as the region has been marked by racial hierarchy and antiblack and antiindigenous racism since the colonial era (Andrews 2004; Wade 1997). For the present argument what matters is Douglass' belief that they represented a preferable alternative to U.S. racial politics, however.
} 
migration and the Americas' political legacy of multiraciality. Reading Douglass as a democratic theorist thus reveals how his arguments about U.S. and Latin American racial politics intersect to formulate what I identify as a fugitive democratic ethos.

The distinctive features of this fugitive democratic ethos can be discerned by bringing together two strands of contemporary thinking on democracy and fugitivity - Sheldon Wolin's notion of "fugitive democracy" and black fugitive thought - thereby extending and amending each in important ways. Wolin (1994) understands democracy as "a project concerned with the political potentialities of ordinary citizens ... becoming political beings through the self-discovery of common concerns and the modes of action for realizing them" (11). He suggests that rather than thinking about democracy as a form of government, it would be more useful to reconceive it as a political moment that is rare and episodic: "a mode of being which is ... doomed to succeed only temporarily, but is a recurrent possibility" (23). Because the enlargement of the circle of those who can participate in politics generally requires the wholesale transformation of existing forms, democracy and revolution are related rather than opposed, and constitutionalism rather than institutionalizing democracy attenuates and limits it, because democratic founding moments are revolutionary moments "that activate the demos and destroy boundaries that bar access to political experience... revolutionary transgression is the means by which the demos makes itself political" (18). Democracy thus requires moments of "democratic renewal" when ordinary individuals can create "new cultural patterns of commonality" (24). Wolin's notion of democratic fugitivity thus envisions democracy as an uneven, multifaceted practice that is never fully achieved.

Douglass' understanding of citizenship/exclusion and approach to constitutional interpretation in his famous "What to the Slave is the Fourth of July" speech of 1852 proleptically articulates Wolin's qualms about the ossification of democracy, while introducing a novel question that Wolin did not consider: What if it is liminal or imperfect citizens ${ }^{3}$ who have an enhanced access to the democratic? In the speech Douglass rhetorically performs the civic in-betweenness of slaves, fugitive ex-slaves, and free African-Americans by continually aligning and disaligning himself with the United States. He simultaneously addresses his white audience as "fellow citizens," yet reminds them that "This Fourth [of] July is yours, not mine. You may rejoice, I must mourn" (Douglass 1996, 116). He interprets the U.S. founding as an anticolonial, revolutionary event in which the rule of law was flouted in the name of higher moral and political principles, suggesting that in the pre-Civil-War era it was not-quite-citizen slaves and fugitive ex-slaves, as well as (black and white) abolitionists who were acting as exemplary citizens. The founding fathers, he argued: "preferred revolution to peaceful submission

\footnotetext{
3 That is, persons who are not yet legal citizens but who act as (and could become) such, and those who are citizens according to the law but are not treated thus in practice.
}

to bondage... They believed in order; but not in the order of tyranny. With them, nothing was 'settled' that was not right... They seized upon eternal principles and set a glorious example in their defence [sic]" (113). Douglass is a fugitive democratic thinker because he emphasizes the revolutionary and unsettled character of democratic politics, and asserts the right of ordinary citizens to interpret the law, such as when he exhorts his audience to read the constitution themselves in order to reach their own conclusions about whether it was an antislavery text (128). In his autobiographies Douglass also suggested that slavery led slaves to develop a different relationship to the law; how else would it have been possible for them to engage in any kind of resistance, particularly escape? "Slaveholders made it almost impossible for the slave to commit any crime, known either to the laws of God or the laws of man. If he stole, he but took his own; if he killed his master, he only imitated the heroes of the revolution" $(2003,69)$. By connecting the law-breaking of fugitive slaves to the U.S. founding, Douglass suggests that these practices should be seen as constitutive to the praxis of citizenship. Douglass' analysis of the experiences of actual fugitives thus alters the temporality of Wolin's concept, as it shows that beyond the evanescence of the political, individuals and groups with precarious claims to citizenship may nevertheless develop enhanced democratic subjectivities. Today's fugitives, we might thus suggest, are the dreamers or Ferguson protesters who enact exemplary democratic practices even as their status as citizens is precarious, and as their political activism renders them vulnerable to increased state reprisal.

In order to fully sketch this dimension of democratic fugitivity that goes beyond Wolin's concept it is thus also necessary to draw upon the tradition of black fugitive thought. ${ }^{4}$ Fugitivity was a strategy that escaped slaves enacted both individually and collectively, and it is a recurring theme in black political thought (Davis 1971). We can provisionally identify a few key features of black fugitive thought: (1) taking seriously as political activities the survival strategies of fugitives: secrecy, concealment, flight, outlawry, etc.; (2) a concern with the creation of autonomous, and at times clandestine, spaces where black political agency can be collectively enacted, which is often coupled with a rejection of the strategy of seeking inclusion into existing racial states due to pessimism about their ability to be reorganized on bases other than white supremacy; (3) embracing the intellectual orientations arising from fugitivity, such as "speaking out of turn" to reveal racial injustice, and imagining alternate racial orders, futures, and forms of subjectivity. Contemporary theorists have attempted to rethink freedom and justice

\footnotetext{
${ }^{4}$ Other attempts to link black fugitivity and democratic theory include Du Bois' formulation of the term "abolition-democracy" in Black Reconstruction, Davis' (2005) use of Du Bois' concept to frame contemporary mass incarceration in light of the civic death of slavery, Balfour's (2011) excavation of the insights about U.S. democracy embedded in Du Bois' textual practices, and GoodingWilliams' (2009) suggestion that Douglass enacted a collective, nonrule-centered form of plantation politics.
} 
from the perspective of the black fugitive (Best and Hartman Fall 2005; Hesse 2014), and Roberts (2015) in particular approaches Douglass as a theorist of fugitivity. He argues that Douglass provides an account of slave agency that allows us to move beyond the stalemate between static, polarized conceptions of negative and positive liberty that dominate debates about freedom in Western political thought: "Douglass develops a tradition of political theory centering attention on the psychological and physical acts of struggle and assertion that are integral to slave agency" (57). Douglass belongs to the tradition of black fugitive thought, not only because he was the most visible African-American fugitive of his time, but also because the experiences of liberation from enslavement and fugitivity shape his political thought in ineluctable ways. He recognized the fugitive's complicated relationship to the law, because in resisting enslavement and stealing themselves, slaves violated laws that did not recognize them as persons, only as chattel. Douglass also theorized the crucial psychological components of liberation-such as when he claimed that he became a free man in fact even though he remained a slave in form after his victory in the climatic battle with the slave-breaker Covey (74-8)thereby revealing fugitivity as not simply a status, but a praxis and disposition.

While Douglass did not fully embrace all the implications of black fugitivity, his approach to democratic politics was shaped by important lessons derived from the actual experience of fugitivity that both extend Wolin's notion of democratic fugitivity and are in tension with it at times. Black fugitive thought, for example, has generally been concerned with the creation of autonomous spaces for black freedom (such as maroon communities) at the margins of or outside colonial states and their successors. Yet Douglass, for the most part, was committed to working toward the refoundation of the U.S. polity on more egalitarian terms; he envisioned its radical transformation based on an expansive notion of multiraciality that would decenter whiteness to an extent that arguably has not been achieved to this day. He may have stopped short of endorsing revolution in the U.S. context, but at key junctures Douglass' concern with black freedom led him to look for models of political agency and black self-government in other parts of the Americas, such as Haiti, which he recognized as a state founded by fugitive slaves (in others words, a maroon state). Douglass' political thought thus displays elements of both democratic fugitivity and black fugitivity. There are potential contradictions and tensions between democratic fugitivity and black fugitivity, however. For instance, democratic engagement requires exposure to the state, but it is precisely the rule of law that is revealed as insufficient and dangerous by the black fugitive; likewise a fugitive democratic orientation would seek to reshape the moral dispositions of the dominant racial order, but black fugitivity is oriented rather to sites of black freedom that refuse or challenge logics of coloniality and the nation-state. I thus trace the tensions between black fugitivity and democratic fugitivity in Douglass' political thought. Sediments of both are present throughout, but black fugitive com- mitments are most evident during those moments when Douglass despairs about the U.S., while fugitive democratic orientations are most apparent during Reconstruction, when he believed a revolutionary moment of democratic renewal was underway.

Most of the texts where Douglass' ideas about Latin America are to be found are in his journalism, thus my analysis of him as a hemispheric thinker draws on both his own writings and instances where he functioned as a curator and chose to publish work that juxtaposed U.S. and Latin American racial formations. The article analyzes three key moments when Douglass engaged with Latin America most closely: his flirtation with AfricanAmerican emigration and search for alternative political spaces of black self-government in Haiti, Nicaragua, and the Mosquito Kingdom in 1852 prior to the U.S. Civil War; his endorsement of the annexation of Santo Domingo in 1870-1871 following the abolition of slavery, in accordance with his vision of a multiracial U.S. polity transformed in part by (nonwhite) immigration; and his defense of Haitian political capacity toward the end of his life, particularly at the 1893 World's Fair. In each of these moments different aspects of an incipient fugitive democratic ethos are on display, but Douglass' commitment to multiracial democracy remains constant throughout. Overall, the article traces Douglass' enduring aspiration to reshape U.S. democracy, for which he found inspiration by enlarging his reflections and investments into a hemispheric mode that encompassed all the (multiracial) Americas.

\section{"A [BLACK] CITY SET ON A HILL": HAITI, NICARAGUA, AND THE MOSQUITO KINGDOM}

It is perhaps not surprising that Douglass' trenchant critique of U.S. democracy in 1852 in his fourth of July speech coincided with the emergence of an enlarged hemispheric sensibility that looked outward to the rest of the Americas for examples of black selfgovernment. In 1852 Frederick Douglass' Paper was the discursive site of African-American reflections about Central America that directly contested U.S. racism in light of political models of multiracial democracy drawn from Nicaragua and the Mosquito Kingdom. Douglass' curatorial practices as a newspaper editor in the 1850s-which highlighted African-Americans' search for sites of black freedom outside the U.S. - can thus be read as a fugitive practice of concealing oneself in the service of sustaining an outlawed exercise of agency. By featuring other African-Americans writing openly about emigration, Douglass was able to champion multiracial democracy without alienating white abolitionists opposed to black equality. Yet AfricanAmerican attempts to enact black fugitivity transnationally ran the risk of establishing proto-imperial relationships vis-à-vis local populations in Latin America, including black and indigenous peoples pursuing their own quests for political autonomy.

Douglass opposed African-American emigration, particularly white colonizationist schemes to remove 
African-Americans to Central America premised on the idea that black and white coexistence on equal terms was impossible in the U.S. (Fredrickson 1987, 149-50). Douglass refused to concede that democracy was only possible in the context of racial homogeneity; he also rejected the idea of separate climatic zones suitable to being inhabited only by certain races (the temperate zone for whites, the tropics for blacks). White colonizationists envisioned a kind of Jim Crow American continent that disavowed the possibility of political co-existence. Douglass' stance on African-American emigration was thus partly driven by his commitment to multiracial democracy.

In contrast, advocates of voluntary black emigration, such as Douglass' onetime co-editor of The North Star and later rival Martin Delany, viewed it as a means of fulfilling black desires for freedom and selfgovernment. Douglass and Delany had a complicated intellectual relationship; they are generally viewed as representative of two diametrically opposed poles within African-American political thought: integrationism and Black Nationalism. Delany was the most famous 19th century proponent of black emigration; unlike Douglass he had given up hope for black equality in the U.S., and highlighted African-Americans' connection to Africa, whereas Douglass emphasized their status as Americans. It is thus Delany rather than Douglass that one would expect to have a hemispheric vision connecting African-Americans to black populations in Latin America. As Levine (1997) and others have noted, however, this simplistic binary opposition overlooks the fact that there was also significant overlap between Douglass and Delany's political ideas: "If Douglass can be viewed as a U.S. nationalist whose racial thinking surfaced at times of stress or dissonance, Delany can be viewed as a racial thinker whose U.S. nationalism expressed itself at moments of hopefulness" (229). This contention is borne out by Douglass' endorsement of black emigration for a brief period prior to the Civil War, when the Dred Scott decision and other developments made the possibility of national inclusion in the U.S. appear distant.

In the 1850s his newspapers promoted emigration to Haiti and Central America, and Douglass himself planned to visit Haiti in order to report on conditions there for those interested in emigration. In "A Trip to Haiti" in Douglass' Monthly in May of 1861, he explained that among his motives for going were "special ones growing out of things at present existing in this country. During the last few years the minds of free colored people in all the States have been deeply exercised in relation to what may be their future in the United States. To many it has seemed that the portents of the moral sky were all against us" (Douglass 1952b, 87-8). Haiti, a maroon state built by rebellious slaves, beckoned disillusioned African-Americans: "looking out into the world for a place of retreat, an asylum from the apprehended storm" (88). In accordance with its prominence in U.S. debates about race and slavery during the 19th century, Haiti played an important role in Douglass' thinking about black freedom. The success of Haiti's experiment in black self-government had im- plications for the cause of black equality everywhere, including the U.S. Douglass explicitly extolled Haiti as an exemplary maroon community where black selfgovernment was a reality:

Born a slave as we were, in this boasted land of liberty... accustomed from childhood to hear the colored race disparaged and denounced, their mental and moral qualities held in contempt, treated as an inferior race, incapable of self-government, and of maintaining, when left to themselves, a state of civilization... we, naturally enough, desire to see, as we doubtless shall see, in the free, orderly and Independent Republic of Haiti, a refutation of the slanders and disparagements of our race. We want to experience the feeling of being under a Government which has been administered by a race denounced as mentally and morally incapable of self-government. (86)

Because of the central place it occupied in U.S. debates about race, civilization, and slavery, "both the press and the platform of the United States have long made Haiti the bugbear and scare-crow of the cause of freedom." One purpose of Douglass' trip was thus to reveal the truth about Haiti, "to do justice to Haiti, to paint her as she is," since "though a city set on a hill, she has been hid" (87). Here, Douglass' journalism was serving black fugitive goals, revealing Haiti as an alternative political ideal principally to U.S. blacks still living under slave law. Haiti was the living enactment of heroic black liberation in which blacks had been the principal actors; it was "the theatre of many stirring events and heroic achievements, the work of a people, bone of our bone, and flesh of our flesh" (85).

This was an era in which Douglass was especially attuned to black fugitivity. In his speech on the anniversary of West India emancipation in 1857, for example, he emphasized the importance of violent resistance by the enslaved (in contrast to his praise for the peaceful process by which it was achieved in the 1880 version of the speech). "The truth concerning the inauguration of freedom," he proclaimed in 1857, was that "a share of the credit of the result falls justly to the slaves themselves... They did not hug their chains;" what British abolitionists were trying to accomplish through persuasion, "the Slaves themselves were endeavoring to gain by outbreaks and violence" (Douglass 1857, 23). This is a moment when Douglass "extols the value of black revolutionary violence as modeled in the Southern Americas" (Levine 2008, 191), in part to exhort U.S. blacks to display the same kind of civic virtue rather than "the stolid contentment, the listless indifference, the moral death which reigns over many of our people" (Douglass 1857, 19). There is an important tension in Douglass' theorization of slave agency between the degradation produced by slavery and the vital necessity of resistance, however, which is mapped onto the comparison between non-U.S. slaves and U.S. blacks in this speech. In the U.S., he argued: "Negroes will be hunted at the North, and held and flogged at the South so long as they... make no resistance, either moral or physical" (22). Yet Douglass did find examples of violent African-American resistance to slavery, such as his rather bloodthirsty suggestion that "every mother who, 
like Margaret Garner, plunges a knife into the bosom of her infant to save it from the hell of... Slavery, should be held and honored as a benefactress" (22). ${ }^{5}$ Yet his U.S. examples of slave resistance all involve individual heroism and inward-directed violence (infanticide and suicide), rather than collective uprisings against slavery.

In 1852, prior to Douglass' invocation of Caribbean models of political agency, Central America was prominently featured as a site of black freedom in Frederick Douglass' Paper. In April 1852 Delany published The Condition, Elevation, Emigration, and Destiny of the Colored People of the United States, in which he identified Central America (and Nicaragua specifically) as one of the most favorable destinations for black emigration (1968). It is not entirely clear whether Delany was already aware that he had been elected (in absentia) mayor of the port of San Juan del Norte when he wrote Condition, and Douglass never reviewed the book. ${ }^{6}$ But Delany's election was covered in Frederick Douglass' Paper, as was African-American emigration to San Juan, and Douglass also published a review of Ephraim G. Squier's Nicaragua, Its People, Scenery, Monuments, and the Proposed Interoceanic Canal. While Douglass did not write any of the articles lauding the Mosquito Kingdom and Nicaragua as examples of black self-government, as publisher of the paper he made the editorial decision to include them. Douglass' curatorial choices as a journalist in 1852 could thus be read as a fugitive practice, whereby the measure of concealment offered by publishing proemigrationist texts written by others allowed him to challenge prevailing racial hierarchies in the U.S.

In his two-part review of Squier's book, which appeared in Frederick Douglass' Paper in January of 1852, James McCune Smith identified both the

\footnotetext{
${ }^{5}$ Douglass' invocation of Garner also raises the question of whether his conception of freedom is masculinist (i.e., whether it reifies male experience as normative). Black feminists, for example, have argued that by repeatedly describing the harms of slavery and exclusion from citizenship as denials of black manhood, Douglass implicitly conceived freedom for black women in a limited form that corresponded to the attenuated civic status of white women (Davis 2010); they have also critiqued the representations of enslaved women in his autobiographies, arguing that he downplayed sexual violence against enslaved women and presented black women's pained bodies as spectacle (Franchot 1990). But Douglass' gender politics are complicated; he also supported women's suffrage and praised their political activism (in the speech cited above, for example, he recognized women's prominence in abolitionist movements), and some readers argue that in the later autobiographies he highlights the role of women, including his mother, grandmother, and the slave-woman Caroline. Situating Douglass within the tradition of black fugitive thought thus also requires considering the relevance of "gendered strategies of freedom" for an assessment of his gender politics, but fully developing this point is beyond the scope of this article.

${ }^{6}$ San Juan's racial and geopolitical topography were complex. Because of its strategic importance as the Atlantic entrance to a possible interoceanic canal it was claimed by both the Mosquito Kingdom and Nicaragua, in a dispute that also involved Great Britain and the U.S. During the colonial era black Creoles and indigenous Miskitus exercised significant autonomy on the Mosquito Coast, but were increasingly subject to Anglo hegemony after Britain officially reestablished its protectorate over the Mosquito Kingdom in 1843, and the discovery of gold in California in 1848 resulted in increased U.S. presence in the region.
}

Mosquito Kingdom and Nicaragua as free states governed by blacks. Writing under the pseudonym "Communipaw," McCune Smith (1852a) explained to his African-American readers that "The British Government claims protection over the mouth of the San Juan, for its ally the colored King of the Musquitos. The American Government claims protection over the rest of the route, for their allies the colored republic of Nicaragua. For Nicaragua is a colored republic!" Mapping the one-drop rule onto Squier's description of Nicaragua's racial composition, McCune Smith observed that taking the "North American view" of the question, "Colored or Negroes" were the majority of the country's population. Reducing those originally counted as white (whose whiteness Squier himself had also questioned), and adding together those in the mixed-race and black categories, McCune Smith concluded that Nicaragua was mostly black, with a significant indigenous population, and few whites. Nicaragua's criollo elite, which tended to downplay the country's black and indigenous ancestry, would have no doubt vigorously disputed this characterization as a black republic, but it is consistent with African-American perceptions of Latin America as more racially egalitarian than the U.S. ${ }^{7}$

In 1852, when slavery was still legal in the U.S., African-Americans found in Nicaragua an inspiring example of a "colored republic" in which blacks/mixedrace people of African descent were exercising political power. McCune Smith (1852a) approvingly cited Squier's statement that in Nicaragua "notwithstanding the diversity of races, distinctions of caste are hardly recognized," and commented on its significance for U.S. debates about the possibility of multiracial democracy: "All classes may aspire to the highest position in Church and State. Hear that, American Colonizationism!... and stand convicted of ignorance or falsehood when you say it is 'neither natural nor desirable that whites and blacks shall live together in the same community." African-Americans found in Central America evidence that both multiracial democracy and black self-government were possible. McCune Smith (1852b) pointedly observed that Nicaragua's Foreign Relations minister at the time, Sebastian Salinas, was a mulatto: "Although Mr. Squiers carefully conceals it, the truth is that Senior Salinas is a black man!...Here in Nicaragua, the ... freest ... region on the face of God's earth, where black and white interchange all the civil and social relations on the same platform... we find a black diplomatist of the first water." Similarly, Douglass would later point to Latin America in a scathing rebuttal of Lincoln's flirtation with colonizationism in the midst of the Civil War in an editorial in Douglass' Monthly in September 1862: "Mr. Lincoln knows that in Mexico, Central America and South America, many

\footnotetext{
${ }^{7}$ While it had outlawed slavery in 1821 , Nicaragua was hardly exempt from racism. In their dispute with the Mosquito Kingdom over ownership of San Juan, for example, Nicaraguan officials deployed a racially coded discourse of civilization and savagery to delegitimize the political capacities of the region's black and indigenous inhabitants (Hooker 2010).
} 
distinct races live peaceably together in the enjoyment of equal rights" (Douglass 1952a, 268).

African-Americans seeking sites of black freedom in Central America confronted complicated racial politics upon their arrival, however, as illustrated by another article about San Juan del Norte that appeared in Frederick Douglass' Paper in May 1852 (a month after the publication of Delany's Condition). James Starkey, an African-American migrant, wrote a letter about attempts to export U.S.-style racial segregation to San Juan. Having departed the U.S. on a vessel captained by a Virginian who enforced segregation aboard the ship, Starkey (1852) expected to be able to meet whites "on equal ground" in San Juan, but was disappointed to find that in "a town containing five hundred inhabitants, of which one hundred are white Americans ... the other four hundred, which are composed of Indians and colored persons from the American States, suffer themselves to be ruled at the will and pleasure of the few pale faces." Even more disturbing was the fact that it was sometimes transplanted African-Americans who sought to enforce racial segregation in deference to the sensibilities of their white customers. Starkey described an incident involving an African-American returning from California with white companions who was refused service by the "colored" landlord of a hotel, which resulted in a sound rebuke by the entire party and their moving to another "hotel kept by a white man... [where they] were entertained alike without distinction." ${ }^{8}$ Starkey sought a space of black freedom in the Mosquito Kingdom, not just from slavery, but also from U.S.-style racial hierarchies:

It is very strange that our people will suffer themselves to be carried away by this 'American character' even here, in a country like this, whose king is a colored man, and the police officers, colored men... And with this colored government, colored persons from the States, seek to enforce what they call the 'American character,' but more justly the slaveholding character, on their own color who come among them... Is it not time that we had begun to appreciate freedom, and real liberty, particularly, in a country like this?

Yet due to the presence of white Americans and transplanted African-American subservience, slavery may not have existed, but blacks were still not free.

Starkey's concern that white immigration to black/mixed-race spaces in Central America could infuse them with "the slaveholding character" that U.S. blacks sought to escape was not unfounded, as the circumstances of Delany's election as mayor of San Juan reveal. Delany's election, which was reported in Frederick Douglass' Paper in May 1852, was orchestrated by a transnational, multiracial political alliance between African-American migrants and San Juan's local black/indigenous/mixed-race inhabitants, against an effort by white U.S. citizens to exclude nonwhites from

\footnotetext{
${ }_{8}^{8}$ Mattox (2009) reads this incident as referring to locals, but throughout the letter the phrase "colored persons from the American States" refers to African-Americans.
}

political participation. "In the San Juan election purportedly won by Delany, white and black U.S. Americans, Jamaicans, Miskito Indians, and Nicaraguans participated, pitting a white Cotton American ticket supported by southern U.S. American residents against a "native and colored' party" (Mattox 2009, 532-3). Delany's election was subsequently annulled, yet this fugitive enactment of multiracial democracy epitomized the contradictions that plagued African-Americans' search for sites of black freedom in Central America. For Carolina (1852), a correspondent to Frederick Douglass' Paper, the event represented an actualization of fugitive democracy, when "the native and colored citizens of San Juan" were impelled to organize politically to counter the exertions of "a portion of the inhabitants of this town ... to deprive us of our rights as citizens, to strip us of the rights of having a voice in choosing our own rulers, to subject us if possible to a system of slavery, equaled only by that of the Southern States of the United States of North America." Read in light of black fugitivity, the precariousness of African-American freedom (and citizenship!) in San Juan is clear, including the threat of re-enslavement. Simultaneously, however, Delany selection as a candidate (when he did not reside in, and had never even visited San Juan) points to the unequal power hierarchies within this transnational alliance. Delany's black emigrationism thus involved a trade-off in which spaces of black freedom for African-Americans might be achieved at the expense of the Mosquito Kingdom's actual (black and indigenous) citizens, who were already involved in a struggle to preserve their political autonomy from Nicaragua, the U.S., and Britain. Douglass' hemispheric vision faced similar tensions.

In the 1850s Douglass (and Delany) found sites of black freedom, models of a black "city on a hill," in Central America that demonstrated that black selfgovernment and multiracial democracy were possible. Douglass' black fugitive sensibilities during this period can be discerned in his decision to allow his newspapers to function as a discursive space where black collective political agency could be envisioned. The tensions inherent in African-American hemispheric visions would become even more apparent following emancipation, however, when Douglass (who rejected U.S. expansionism while slavery persisted) endorsed the incorporation of willing Caribbean nations as a means of remaking the U.S. in their more multiracial and (ostensibly) racially egalitarian image.

\section{"A BLACK SISTER TO MASSACHUSETTS": U.S. EXPANSIONISM AND MULTIRACIAL DEMOCRACY}

Douglass' support for the annexation of Santo Domingo (the Dominican Republic) in $1870-1871$ is generally viewed as consistent with his U.S. nationalism. Without excusing his support for annexation, I suggest that Douglass' commitment to multiracial democracy informed his position in ways that have not been sufficiently appreciated. At this time Douglass 
had a much more negative assessment of the political capacities of the black republics of the Caribbean, while he also viewed the Reconstruction-era U.S. as the vanguard of racial egalitarianism in the hemisphere. During this period the fugitive democratic elements of Douglass' political thought eclipse black fugitivity. His support for annexation was driven by the view that the willing incorporation of black/mixed-race Latin American states on terms of full equality would transform U.S. racial politics by contributing to "a diverse U.S. American identity that decentered whiteness" (Polyné 2010, 29). Douglass' comitment to refounding U.S. democracy on more racially egalitarian groundspartly via expanded immigration grounded in the notion of a universal human right to migration - led him to underestimate the threat U.S. expansion posed to black freedom and sovereignty in the Caribbean.

During the 19th century U.S. views about expansion to Latin America were shaped by attitudes toward slavery and racial hierarchy. Prior to the Civil War white southerners promoted U.S. expansion as a way to increase the number of slave states, while abolitionists opposed it for precisely this reason. During Reconstruction, however, a reversal occurred, and many white southerners (driven by similar ideas as in the past: opposition to racial equality and a desire to enforce racial separation and white supremacy) opposed U.S. expansion to Latin America because it entailed the incorporation of nonwhites as citizens. Douglass' position also shifted. Consistent with his opposition to racial segregation on a hemispheric level between a "white" U.S. and black/brown Latin America, he rejected racist arguments against annexation. ${ }^{9}$ Douglass supported voluntary annexation because he believed it could be beneficial to both Santo Domingo and the United States: it would help the former overcome the legacy of slavery and the deficient political culture inherited from Spain, and it would enhance the latter's emerging "composite nationality." His support was contingent on certain parameters for annexation, however: it could not occur by force, a majority of Dominicans had to support it, and the Dominican government should freely agree to it. "While we would gladly see San Domingo, Hayti, Cuba, and all the islands of the Caribbean Sea made a part of the United States... If we cannot have them without dishonor, rapine, and bloodshed let them stay out forever" (Douglass 1871).

Much of the opposition to annexation was rooted in racist anxieties about the deleterious effects of incorporating black/mixed-race Caribbean bodies into the U.S. Since African-Americans had obtained the right to vote in 1870, Southern Democrats worried that annexation would add more black voters who would vote $\mathrm{Re}$ publican, and contribute to the creation of a nonwhite majority that would entrench "black supremacy." Opponents of annexation also objected based on pseudoscientific ideas about race and climate; "anti-imperialist racists ... were concerned about a plan that would add

\footnotetext{
9 Douglass became involved in the debate over annexation after President Grant appointed him assistant secretary to the Commission of Inquiry for the Annexation of Santo Domingo in 1871.
}

'tropical' blacks to the U.S. nation" (Levine 2008, 207). Senator Carl Schurz of Missouri, for example, imagined the following nightmare scenario: "fancy the Senators and Representatives of ten or twelve millions of tropical people, people of the Latin race mixed with Indian and African blood... fancy them sitting in the Halls of Congress, throwing the weight of their intelligence, their morality, their political notions and habits, their prejudices and passions, into the scale of the destinies of this Republic" (209). Claims about the existence of natural geographic zones where only certain races could flourish even found their way into the arguments of Senator Charles Sumner, Douglass' political ally and champion of African-American rights. Sumner framed his opposition to annexation as a defense of the right to self-government of nonwhite peoples (Haiti in particular), but he also argued that "by a higher statute is that island [Hispaniola] set apart to the colored race. It is theirs by right of possession ... by tropical position ... and by unalterable laws of climate. Such is the ordinance of nature, which I am not the first to recognize" (207). Douglass rejected the idea of a link between race and climate, and the ensuing vision of a Jim Crow American continent composed of racially homogeneous nation-states. "We fail to see any serious objection to the measure on the grounds that the tropics, especially belong to the colored race... we are opposed to this parceling out the earth to different varieties of men-locating one here and another there, and deeming this one and that out of its place, here or there... reason, aptitude, and ability, rather than color ... must determine where ... a race of men must live" (Douglass 1871).

Douglass developed a self-consciously global and cosmopolitan notion of multiracial democracy grounded in the idea of a universal human right to migration and the Americas as a multiracial space. In an 1869 lecture on the United States' emerging "Composite Nationality," for example, he connected the fact that "until recently, neither the Indian nor the negro has been treated as a part of the body politic" to Chinese immigration. Responding to those who wondered, "Should not a superior race protect itself from contact with inferior ones? Are not the white people the owners of this continent? Have they not the right to say what kind of people shall be allowed to come here and settle?" Douglass replied "There are such things in the world as human rights. They rest upon no conventional foundation, but are eternal, universal and indestructible. Among these is the ... right of migration ... which belongs to no particular race, but belongs alike to all and to all alike." Observing that it was only by virtue of said right that European settlers and their descendants could justify their presence in the Americas, he affirmed, "I reject the arrogant and scornful theory by which they [whites] would limit migratory rights, or any other essential human rights, to themselves, and which would make them the owners of this great continent to the exclusion of all other races of men. I want a home here not only for the negro, the mulatto and the Latin races, but I want the Asiatic to find a home here in the United States, and feel at home 
here, both for his sake and ours" (Douglass 1979, 245 6 , 252). Perhaps we can detect a residue of the black fugitive's refusal to be bound by the nation-state in Douglass' idea of a right to migration.

If Douglass supported annexation because it coincided with his view that the U.S. should embrace immigration, he also believed that it would be advantageous to Santo Domingo, particularly by helping to transform the deficient political institutions inherited from Spain and the distorted cultural habits that were the legacy of slavery. Annexation, he argued, should be viewed not in terms of "what Santo Domingo can do for us, but... [rather] what we can ... and ought to do for Santo Domingo" (Douglass n.d., 3). In contrast to his earlier positive perception of Haiti, Douglass described Santo Domingo as an island ruled by two governments, "both republican in form, yet both military and despotic in fact" (1). He attributed this political dysfunction partly to the legacy of Spanish colonization: "In Santo Domingo were first planted the virtues and the vices, the beauties and deformities of European civilization ... Spain, to whom it belonged ... was as remarkable for her piety as she was for her cruelty" (5-6). Douglass' critique of Spain echoes that of Latin American intellectuals, such as Domingo F. Sarmiento, who in Facundo in 1845 famously ascribed Argentina's political disorder partly to the stultifying effects of Spanish colonization (2004). Douglass similarly attributed Santo Domingo's sluggish and unimaginative national character to Spain's intolerance of religious diversity, and even suggested that "Dark and sanguinary as may have been the barbarism of the island, prior to its discovery and settlement by the Spaniards, the state of things which then existed seems to have been far more friendly to human life and happiness than after it ... [came into] the hands of the Christian Spaniards" (Douglass n.d., 13).

Douglass also attributed Santo Domingo's political disorder and economic underdevelopment to the legacy of slavery. Rather than emphasizing slave agency as he had earlier, Douglass focused on slavery's deforming effects on the enslaved: "When we think of the slavery, both of the natives, and the Africans in that Island; when we think of the ten thousand evils that slavery entailed upon that country ... the indolence and repugnance to labor which slavery left behind it, and the misrule, and bad government which have followed to this day...the wonder is not that civilization is feeble, but that there is civilization at all" (15). Slavery contributed to political instability by fostering a political culture prone to violence and disorder: "While a large portion of the people of Santo Domingo are peaceable and orderly... owing to the ignorance and barbarism left them by slavery, they are the sports of designing chiefs, of educated and ambitious leaders who manage to keep the country in a chronic state of revolution" (21).

During Reconstruction Douglass' commitment to the U.S. was at its apex, because he believed it was in a process of radical re-founding, and he retreated from political ideas consonant with black fugitivity. Hence the paternalistic overtones of his arguments about the beneficial effects of transplanting U.S. political institutions to Caribbean nations, such as the claim that there would be no greater achievement for "the Anglo-Saxon race" than "the redemption of the tropics from Latin mis-rule, ignorance and superstition" (22-3). Douglass viewed the U.S. as the vanguard of racial egalitarianism in the Americas at this moment. Explaining his switch from opponent to supporter of U.S. expansionism, he observed "That was a time when extension meant more slavery, more ignorance and barbarism, but that time is now gone by. Extension now means freedom ... this Republic is now the hope of freedom throughout the world" (26-7). Writing at the height of Reconstruction, when racial equality seemed like a distinct possibility, Douglass linked his support for expansion to progress toward multiracial democracy:

\begin{abstract}
All signs indicate that ... the continent is ultimately to belong to us. Latin civilization, the only present obstacle to our southern dominion, is rapidly getting itself into the grave... The sentiments of our people are shaping themselves for this multiform composite nationality. Prejudice against color once thought to be natural and invincible alike to time and reason, can no longer be relied upon. The idea that this is exclusively the whitemans [sic] countryand the whitemans [sic] government-has already become a superstition. The irrepressible negro ... is now a member of Congress, and elegeable [sic] to any office of honor or profit in the land. (Douglass 1872-1873, 8-9)
\end{abstract}

It was precisely by contributing to the democratic ideal of making it no longer "exclusively the white man's country" that the annexation of Santo Domingo would be beneficial to the U.S. Douglass believed that the voluntary incorporation of Latin American states would help transform the U.S. into a more racially egalitarian and multiracial polity. Annexation "would make her [Santo Domingo] the black sister to Massachusetts, and transplant within her tropical borders the glorious institutions which have lifted that grand old Commonwealth to her present commanding elevation... Since the downfall of slavery and the enfranchisement of the colored race, we have recognized the composite character of the nation, and considered it a blessing rather than a misfortune" (Douglass 1871).

Douglass envisioned a multiracial U.S. democracy in which whiteness was decentered in multiple ways: through political and social equality for AfricanAmericans and Native Americans, Asian immigration, and the addition of black/mixed race Latin Americans, all of whom would be integral elements of a new "composite nationality" (Douglass 1979, 259). Douglass' notion of multiraciality, rather than a blending together of different ingredients into a homogenous whole, is precisely captured by some of the definitions of "composite" in the Oxford English Dictionary: "Made up of various parts or elements... Consisting of an organic aggregation of individuals, or of distinct parts ... made from two or more physically different constituents each of which largely retains its original structure and identity" (2014). Douglass' notion of composite nationality illustrates the fugitive democratic elements of his political thought because it envisions the discovery of 
common goals of racial redress and material survival among ordinary persons in order to depose racial oligarchy. He welcomed the idea of a nonwhite majority that would transform white supremacy, such that "the old question as to what shall be done with the negro will have to give place to the greater question 'what shall be done with the Mongolian, and perhaps we shall see raised one still greater, namely, "what shall the Mongolian do with both the negro and the white?"' (Douglass 1979, 249-50). The U.S. was uniquely suited to become the site of such a composite nationality because of its anticolonial, revolutionary foundation: "our greatness... will be found in the faithful application of the principle of perfect civil equality to the people of all races and creeds. We are not only bound to this position by our organic structure and by our revolutionary antecedents but by the genius of our people. Gathered here from all quarters of the globe, by a common aspiration for national liberty as against caste, divine right and privileged classes" (22-3). Grounded in a cosmopolitan notion of the virtue of migration, Douglass argued that the U.S. "should welcome... all nations ... tongues and peoples, and as fast as they can learn our language and comprehend the duties of citizenship, we should incorporate them into the American body politic" (27). He thus took the nightmare scenario of the anti-annexationists and reshaped it into a fugitive democratic vista in which U.S. democracy would be enhanced by having a "black sister to Massachusetts" of Caribbean origin.

Douglass was undoubtedly overly optimistic in his hopes that Reconstruction-era racial inclusion constituted a permanent democratic recomposition of the U.S. polity, but his ringing endorsement of immigration a century and a half ago is striking in light of some of the contemporary xenophobic responses to the border crisis created by the influx of undocumented Central American children fleeing gang violence in 2014. Efforts to enact multiracial democracy during Douglass' lifetime evoked many of the same fears and racial resentment elicited by the country's changing demographics and the election of its only African-American president. Douglass (1872-1873) was startlingly prescient about such fears; he observed that for some of his contemporaries African-American enfranchisement had conjured a "new danger... the phantom of black supremacy," and reassured them that "Black supremacy need not much disturb you" as it was an as yet distant prospect $(4,13)$. He may have mocked fears of a "black emperor," but Douglass certainly envisioned the transformation of the U.S. polity via an expanding multiracial citizenry that would challenge white supremacy. In contrast to his search for sites of black freedom and racial egalitarianism in Latin America in the 1850s, during Reconstruction Douglass endorsed expansionism in order to transform the U.S. into his vision of a city on a hill: a multiracial democracy with a composite nationality in which individuals of "all races and creeds" could be equal co-citizens. The failure of Reconstruction would render Douglass much more skeptical about the prospects of multiracial democracy in the U.S., however. As a result, traces of black fugitivity resurfaced in his thinking in the 1890s, and he once again highlighted Haiti as an exemplary site of black freedom linked to African-Americans by transnational forms of racial solidarity.

\section{"WE MUST RISE OR FALL WITH THE RACE": BLACK FUGITIVITY AND RACIAL SOLIDARITY}

The final sentence of the 1892 edition of Douglass' third autobiography, The Life and Times of Frederick Douglass (published three years before his death), reads: "I have been the recipient of many honors, among which my unsought appointment... to represent the United States to the capital of Haiti, and my equally unsought appointment... to represent Haiti... at the World's Columbian Exposition, are crowning honors to my long career and a fitting and happy end to my whole public life" (Douglass 2003, 453). That Douglass would cite this as a fitting coda to his extraordinary life might come as a surprise to both Caribbean critics of his promotion of U.S. foreign policy in the region, and to those who view him as a parochial AfricanAmerican thinker. Yet that Douglass would choose to discursively locate himself in Haiti at this time is consistent with his defense of Haitian sovereignty and political capacity in the 1890 s. Coupled with his curation of the Haiti exhibit at the 1893 World's Fair, this is a moment when Douglass recaptures some of his earlier black fugitive commitments by foregrounding the heroic collective struggle for liberation of Haitian slaves as an exemplary political act. Nevertheless, Douglass' attempt to enact a transnational form of black solidarity in the 1890s suffered from similar tensions as African-American quests for black freedom in Central America in the 1850s. Throughout his career Douglass was caught between the two polarities of democratic and fugitive hope. Democratic hope recognizes democracy's impermanent, contingent, and imperiled character but nevertheless remains committed to the struggle to perfect it, whereas black fugitive hope seeks to enable black freedom while maintaining distance from slavery's afterlife and white supremacy because the polity is not easily reconstituted on more racially egalitarian grounds. Douglass vacillated between these two poles, and we find traces of both in his engagement with Haiti at the end of his life.

Douglass served as U.S. Minister Resident and Consul General to the Republic of Haiti from 1889 to 1891, a tenure marked by controversy over the Môle St. Nicolas. The failure to secure a lease of the Haitian port of Môle St. Nicolas as a U.S. naval fueling station would lead to Douglass' resignation in 1891 and to a public dispute over who was responsible for the failure of the negotiations. Rather than accept that Haiti, as an independent republic, had rejected an arrangement that Haitians perceived as a breach of national sovereignty, the U.S. press blamed Douglass (who was not the lead negotiator) and suggested that his racial sympathies had compromised his ability to defend U.S. interests. Douglass' criminalization in the press (through 
implicit accusations of treason) figuratively returned him to the status of a fugitive whose national belonging was in doubt. Disgusted with U.S. efforts to strong-arm Haiti into submitting to the lease, and distressed by his portrayal in the press, Douglass published two articles shortly after his resignation that exposed the racist logic behind the criticisms.

Douglass claimed not to have opposed the idea of the lease per se, as "the concession asked for was in the line of good neighborhood and advanced civilization, and in every way consistent with the autonomy of Haiti," but rather to have objected to the manner in which the U.S. sought to gain Haitian agreement to it (Douglass 1891, 343-4). He then exposed the hypocrisy of claims that a white diplomat would have been able to establish better relations with Haiti:

One of the duties of a minister in a foreign land is to cultivate good social as well as civil relations with the people and government to which he is sent. Would an American white man, imbued with our national sentiments, be more likely than an American colored man to cultivate such relations? Would his American contempt for the colored race at home fit him to win the respect and good-will of colored people abroad? Or would he play the hypocrite and pretend to love negroes in Haiti when he is know to hate negroes in the United States? ... Haiti is no stranger to Americans or American prejudice. Our white fellowcountrymen have taken little pains to conceal their sentiments. (339)

The only putative advantage gained by appointing a white diplomat was the expectation of more deference by Haiti, an assumption that betrayed ignorance of the country's history. Douglass also cited his prior support for the annexation of Santo Domingo as evidence that he was not uniformly opposed to U.S. expansionism in Latin America, but rather wanted the U.S. to treat Latin American nations as equals, and to have such incorporation be voluntary and mutually beneficial. The U.S., "should ask nothing of Haiti on grounds less just and reasonable than those upon which they would ask anything of France or England... Are we to wring from it by dread of our own power what we cannot obtain by appeals to its justice and reason? If this be the policy of this great nation, I own that my assailants were right when they said that I was not the man to represent the United States in Haiti" (Douglass 1891, 339-40). Douglass' futile attempt to enact horizontal hemispheric relations was thus incompatible with U.S. racism and imperialism.

If the negative reaction in the U.S. to Douglass' egalitarian approach to hemispheric relations reflects a process by which he was "blackened" (i.e., where he was seen as too sympathetic to Haiti because of his race), Caribbean intellectuals critical of his role engaged in an inverse "whitening" of Douglass, where they viewed him solely as an agent of U.S. empire. The Cuban nationalist José Martí, for example, writing in exile from New York for the Argentinean newspaper La Nación in 1889, described Douglass in rather disparaging terms:
About Haiti there has been a scandal in these days because the minister sent by the United States is the gray-haired mulatto Douglass, married to a white woman; and he goes there to tell them that they should love the United States and especially the Republicans that are currently in power, because they have been like a father to the black man, and the blacks of the Americas should place themselves in their [capable] hands and follow them if they wish to be saved.

Martí did not mince words about what he viewed as Douglass' complicity in U.S. imperial ventures in the Caribbean, and even accused him of being animated by greed: "[for] Douglass, who has rented out his old age ... those [Caribbean] waters are not unknown, because he voyaged in them years ago, as a commissioner for Grant, when there was a plan for the annexation of Santo Domingo" (Martí 1964, 351-2). As Arroyo (2011) has observed, Martí's critique of Douglass on behalf of Haitian sovereignty is ironic given that most Spanish Caribbean "intellectuals turned their backs on Haiti because the country clearly mirrored their own socio-political fears for their nations ... becoming a black nation governed by blacks." In contrast to this widespread denial and disavowal of the Haitian revolution (Fischer 2004), in the 1890s Douglass would again cite Haiti as an inspiring black collective freedom project that was even more exemplary for having been enacted by rebellious slaves.

The tensions between black fugitivity and democratic fugitivity in Douglass' political activities during this era are perhaps most evident in his curation of the Haitian exhibit at the 1893 World's Columbian Exposition in Chicago. In keeping with the heightened exclusion and racial domination that characterized the post-Reconstruction era, African-Americans were not represented in any of the U.S. exhibits, as the Exposition's spatial design followed a white supremacist logic whereby "the sequence of exhibits was supposed to demonstrate the advance of civilization from socalled primitive cultures, such as those in Africa, to the supposedly higher stages represented by Europe and North America" (Westerbeck 1999, 146). Having been asked by Haiti's government to organize their country's exhibit, Douglass was able to ensure AfricanAmerican inclusion. The Haitian pavilion displayed the writings of notable African-American intellectuals (such as Paul Laurence Dunbar and Ida B. Wells), and became a site for the celebration of African-American achievements since emancipation. Douglass and Wells (1893) also produced a phamplet that simultaneously documented African-American progress and the escalating forms of racial terror they faced, including an essay by Wells on lynching. In his introductory essay to the volume Douglass unflinchingly lists the many failing of U.S. democracy due to the persistence of the "spirit of slavery:" "We would like ... to tell our visitors that... American law is now the shield alike of black and white... that here Negroes are not tortured, shot, hanged, or burned to death merely on suspicion of crime... that the American Government is in reality a Government of the people, by the people and for the people, for all the people... But unhappily, none 
of this can be said without ... flagrant disregard for the truth" (3-4).

Douglass' curatorial practices at the Exposition can be read in multiple ways. Viewed in light of fugitive democracy, they could be seen as facilitating a fleeting mobilization of the demos in which symbolic AfricanAmerican inclusion coupled with vivid demonstrations of attenuated black citizenship together functioned to petition the racial state for inclusion. From the perspective of black fugitivity, however, this was a dangerous strategy in a polity constituted by white supremacy, as it might invite enhanced punishment and surveillance of blacks, especially ordinary African-Americans. For the fugitive democrat this risk would be preferable to giving in to the temptation of democratic despair, but the black fugitive would presumably seek alternative sites/forms of liberation. Additionally, Douglass' curation of the Haiti exhibit could also be read as a moment when the power hierarchies that plagued earlier attempts to link black struggles across the Americas resurfaced, when prominent African-Americans' quest for citizenship once again displaced, if not erased, the autochthonous political concerns of local black populations (in this instance Haitians).

Perhaps a less equivocal example of Douglass' invocation of the distinctive freedom of the black fugitive was the powerful lecture on Haiti he delivered at the Exposition, in which he rearticulated the notion of Haiti as a black city on a hill and celebrated the political activities of revolutionary Haitian slaves. The official purpose of the Exposition was to commemorate the 400th anniversary of Columbus' arrival in the Americas, but in his January 2, 1893 lecture inaugurating the Haitian pavilion, Douglass reframed the event and turned it into a celebration of the 90th anniversary of Haitian independence in 1804 and the establishment of "the only self-made black republic in the world." Rather than a celebration of the advent of European colonialism, it became a celebration of the revolutionary activities of rebellious slaves. The Haitian revolution, Douglass argued was "one of the most remarkable... events... in the history of mankind." Comparing it to the U.S., he observed that the founding fathers benefitted from "long years of personal and political freedom. They belonged to the ruling race of this world and the sympathy of the world was with them." In contrast, the Haitian revolutionaries "were slaves... Their education was obedience to the will of others... Yet from these men of the negro race came brave men, men who loved their liberty more than life [Applause]; wise men, statesmen, warriors and heroes... men who have gained their independence against odds as formidable as ever confronted a righteous cause or its advocates" (Douglass 1893, 21-2). It was the courage, resilience, and sagacity of the enslaved who fought for freedom that accounted for Haiti's enduring power as a political example: "It will ever be a matter of wonder and astonishment to thoughtful men, that a people in abject slavery, subject to the lash, and kept in ignorance of letters, as these slaves were, should have known enough, or have had left in them enough manhood, to combine, to organize, and to select for themselves trusted leaders and with loyal hearts to follow them into the jaws of death to obtain liberty" (15-6). Douglass also reiterated a frequent trope in his work that struggling for freedom from enslavement was the source of valuable political lessons that could not be taught: "the freedom of Haiti was not given as a boon, but conquered as a right!" (16).

Douglass also articulated an alternative political lineage for the Americas that equally foregrounded the contributions of its black ancestors, suggesting alternative currents of circulation of ideas and practices, not only of slavery, but also of freedom. Haiti was an exemplary American space because

She was the first of all the cis-Atlantic world, upon which the firm foot of the... white man was permanently set... She was also the first to witness the bitter agonies of the negro bending under the blood-stained lash of Christian slave-holders. Happily too, for her, she was the first of the New World in which the black man asserted his right to be free and was brave enough to fight for his freedom and fortunate enough to gain it. (10)

Douglass's use of the term "cis-Atlantic" recalls Paul Gilroy's (1993) notion of the black Atlantic; his invocation of the Haitian revolution as part of the political legacy of the Americas is likewise reminiscent of the notions of diasporic routes connecting free and enslaved black populations. In contrast to his emphasis on Santo Domingo's deficient political culture in the 1870s, here Douglass attributed Haiti's political problems to self-interested Haitian and U.S. elites, not any racial or cultural defect. Haiti's political instability had nothing to do with "the character of the race," he argued: "The common people of Haiti ... have no taste for revolutions. The fault is not with the ignorant many, but with the educated and ambitious few. Too proud to work ... they make politics a business of their country... I wish I could say that these are the only conspirators against the peace of Haiti, but I cannot. They have allies in the United States" (7).

Douglass' articulation of a notion of transnational black solidarity based in part on shared subjection to antiblack racism and the linkages forged by rebellious slaves in his 1893 lecture on Haiti further reinforces the claim that this was a moment when he once again looked beyond the U.S. to the rest of the Americas for political inspiration. He displayed a black fugitive sensibility by envisioning a non-nation-state based solidarity that could engender freedom and cultivate distance from white supremacy. At the outset of the lecture, for example, he argued that Haiti was intimately linked to black struggles everywhere, including those of AfricanAmericans:

[T]he people of Haiti, by reason of ancestral identity, are more interesting to the colored people of the United States than to all others, for the Negro... can never part with his identity and race... No matter where prosperity or misfortune may chance to drive the negro, he is identified with and shares the fortune of his race. We are told to go to Haiti; to go to Africa. Neither Haiti nor Africa can save 
us from common doom. Whether we are here or there, we must rise or fall with the race. (11)

Douglass also invoked links forged on the basis of exemplary political actions, such as the Haitian revolution, that exemplified universal civic virtues:

Haiti is the black man's country, now forever... She has grandly served the cause of universal human liberty. We should not forget that the freedom you and I enjoy today; that the freedom that eight hundred thousand colored people enjoy in the British West Indies; the freedom that has come to the colored race the world over, is largely due to the brave stand taken by the black sons of Haiti ninety years ago. When they struck for freedom, they builded [sic] better than they knew... They were linked and interlinked with their race, and striking for their freedom, they struck for the freedom of every black man in the world. (14)

In the 1890s Douglass found in Haiti a model of black political agency that served as the basis for a form of fugitive hope. Having recognized the fragile character of the United States' commitment to racial egalitarianism following Reconstruction, Douglass chose to highlight Haiti as the source of an alternative founding genealogy for all of the Americas committed to racial justice and enacted by heroic ex-slaves.

This article has sought to highlight a different dimension of Frederick Douglass as a democratic theorist, and to show that Latin America played an oftenoverlooked yet important role in shaping his political thought, particularly his arguments about multiracial democracy. A key element of Douglass' democratic vision, which was informed by black fugitivity, was an enlarged account of political founding moments that foregrounded the contributions of nonwhites and the development of a broad and inclusive notion of an American (in the hemispheric sense) political inheritance. Recovering this element of Douglass' political thought has important methodological implications for political theory, and comparative political theory in particular. For instance, the dominant impulse in the field to turn to Europe for political models and ideas (which is replicated in comparative political theory by comparisons between Western and nonWestern thinkers) may conceal important arguments that emerge as crucial in different geopolitical and intellectual contexts. My hope is that this analysis of how Douglass enables a conversation about the fruitfulness of rethinking democracy in light of black fugitive thought demonstrates that we also have much to learn from hemispheric geographic and conceptual frames that rigorously interrogate the intellectual connections and political genealogies of the Americas.

The fugitive democratic ethos that can be extracted from Douglass' political thought is particularly relevant today because it can serve as a resource in ongoing debates about racial justice, cultural diversity, and U.S. democracy. There is a striking parallel between 19th century fears of black supremacy elicited by attempts to enfranchise African-Americans and contemporary accusations of executive overreach and Caesarism against President Obama. Douglass' call for nonwhite incorporation in order to overcome white supremacy also stands in stark contrast to contemporary hostility toward Latino immigrants grounded in fears about the "browning" of the country and the displacement of its Anglo-Saxon political culture. His embrace of a composite U.S. nationality fueled by immigration in order to build an egalitarian multiracial polity where solidarities could be forged across racial and cultural boundaries serves as an important counterpoint to arguments that such developments threaten both whites' demographic majority and African-American interests. Highlighting the hemispheric valences within African-American political thought also upends the claim that only Latin America has produced positive conceptions of multiracial democracy. In light of recent attempts to read Douglass as an unabashed believer in the redemptive power of a deracialized American liberalism, it is also especially useful to highlight his at times quite radical black fugitive commitments to racial justice. When Douglass proclaimed of Haitian slaves, "when they struck for freedom they builded better than they knew," he should also be read as staking a claim for the revolutionary potential and relevance of black fugitivity as a resource for rethinking the spatial logic, temporal contours, and intellectual lineage of democratic theory.

\section{REFERENCES}

2014. Composite. In Oxford English Dictionary Online: Oxford University Press.

Andrews, George Reid. 2004. Afro-Latin America, 1800-2000. New York: Oxford University Press.

Arroyo, Jossianna. 2011. "Revolution in the Caribbean: Betances, Haiti and the Antillean Confederation." La Habana Elegante 49 (Spring/Summer).

Balfour, Lawrie. 2011. Democracy's Reconstruction: Thinking Politically with W.E.B. Du Bois. New York: Oxford University Press.

Best, Stephen, and Saidiya Hartman. Fall 2005. "Fugitive Justice." Representations 92 (1): 1-5.

Boxill, Bernard. 1992-1993. "Two Traditions in African-American Political Philosophy." The Philosophical Forum 24 (1-3): 119-35.

Buccola, Nicholas. 2012. The Political Thought of Frederick Douglass: In Pursuit of American Liberty. New York: New York University Press.

Carolina. 1852. "San Juan de Nicaragua." Frederick Douglass' Paper, May 6.

Communipaw. 1852a. "Nicaragua.” Frederick Douglass' Paper, January 8.

Communipaw. 1852b. "Nicaragua - No. II." Frederick Douglass' Paper, January 15.

Davis, Angela Y. 1971. Lectures on Liberation. Los Angeles: National United Committee to Free Angela Davis.

Davis, Angela Y. 2005. Abolition Democracy: Beyond Empire, Prisons, and Torture/Interviews with Angela Y. Davis. New York: Seven Stories Press.

Davis, Angela Y. 2010. "Introduction." In Narrative of the Life of Frederick Douglass, an American Slave, Written by Himself: A New Critical Edition, 21-37. San Francisco: City Lights Publishers.

Delany, Martin R. 1968. The Condition, Elevation, Emigration, and Destiny of the Colored People of the United States. New York: Arno Press.

Douglass, Frederick. 1857. "West India Emancipation." In Two Speeches by Frederick Douglass, one on West India Emancipation and the other on the Dred Scott Decision. Rochester, NY: C. P. Dewey, 3-24.

Douglass, Frederick. 1871. "Annexion of San Domingo." The New National Era, January 12. 
Douglass, Frederick. 1872-1873. "Reminiscences of the Anti-Slavery Conflict" (as delivered during the lecture season of 1872-1873). In Frederick Douglass Papers: Library of Congress.

Douglass, Frederick. 1891. "Haiti and the United States. Inside History of the Negotiations for the Môle St. Nicholas. I." The North American Review 153 (418): 337-45.

Douglass, Frederick. 1893. Lecture on Haiti. Chicago, IL: Violet Agents Supply Co.

Douglass, Frederick. 1952a. "The President and His Speeches." In The Life and Writings of Frederick Douglass, Vol III: The Civil War, 1861-1865, ed. Philip S. Foner. New York: International Publishers, 266-70.

Douglass, Frederick. 1952b. "A Trip to Haiti." In The Life and Writings of Frederick Douglass, Vol. III: The Civil War, 18611865, ed. Philip S. Foner. New York: International Publishers, $85-8$.

Douglass, Frederick. 1979. "Our Composite Nationality: An Address delivered in Boston, Massachusetts, on 7 December 1869.' In The Frederick Douglass Papers, Series One: Speeches, Debates and Interviews, Vol. 4: 1864-80, eds. John W. Blassingame and John R. McKivigan. New Haven: Yale University Press, $240-59$.

Douglass, Frederick. 1996. "What to the Slave is the Fourth of July." In The Oxford Frederick Douglass Reader, ed. William L. Andrews. New York: Oxford University Press, 108-30.

Douglass, Frederick. 2003. The Life and Times of Frederick Douglass. 1892 ed. Mineola, NY: Dover Publications.

Douglass, Frederick. n.d. "Santo Domingo." In Frederick Douglass Papers: Schomburg Center for Research in Black Culture.

Douglass, Frederick, Ida B. Wells, et al. 1893. The Reason Why The Colored American Is Not In The World's Columbian Exposition. Frederick Douglass Papers: Library of Congress.

Fischer, Sibylle. 2004. Modernity Disavowed: Haiti and the Cultures of Slavery in the Age of Revolution. Durham: Duke University Press.

Franchot, Jenny. 1990. "The Punishment of Esther: Frederick Douglass and the Construction of the Feminine." In Frederick Douglass: New Literary and Historical Essays, ed. Eric J. Sundquist. Cambridge, England: Cambridge University Press, 141-65.

Fredrickson, George M. 1987. The Black Image in the White Mind: the Debate on Afro-American Character and Destiny, 1817-1914. Middletown, CT: Wesleyan University Press.

Gilroy, Paul. 1993. The Black Atlantic: Modernity and Double Consciousness. Cambridge, MA: Harvard University Press.

Gooding-Williams, Robert. 2009. In the Shadow of Du Bois: AfroModern Political Thought in America. Cambridge, MA: Harvard University Press.
Hesse, Barnor. 2014. "Escaping Liberty: Western Hegemony, Black Fugitivity." Political Theory 42 (3): 288-313.

Hooker, Juliet. 2010. "Race and the Space of Citizenship: The Mosquito Coast and the Place of Blackness and Indigeneity in Nicaragua." In Blacks \& Blackness in Central America: Between Race and Place, eds. Lowell Gudmundson and Justin Wolfe. Durham: Duke University Press, 246-77.

Krause, Sharon R. 2002. Liberalism with Honor. Cambridge, MA: Harvard University Press.

Levine, Robert S. 1997. Martin Delany, Frederick Douglass, and the Politics of Representative Identity. Chapel Hill: University of North Carolina Press.

Levine, Robert S. 2008. Dislocating Race and Nation: Episodes in Nineteenth-Century American Literary Nationalism. Chapel Hill: University of North Carolina Press.

Martí, José. 1964. "Carta al Señor Director de La Nación, 30 de Octubre de 1889." In Obras Completas. La Habana: Editorial Nacional de Cuba, 347-55.

Mattox, Jake. 2009. "The Mayor of San Juan del Norte? Nicaragua, Martin Delany, and the 'Cotton' Americans." American Literature 81 (3): 527-54.

Mignolo, Walter. 2006. The Idea of Latin America. New York: WileyBlackwell.

Myers, Peter C. 2008. Frederick Douglass: Race and the Rebirth of American Liberalism. Lawrence, KS: University Press of Kansas.

Nwankwo, Ifeoma K. 2005. Black Cosmopolitanism: Racial Consciousness and Transnational Identity in the Nineteenth-Century Americas. Philadelphia: University of Pennsylvania Press.

Polyné, Millery. 2010. From Douglass to Duvalier: U.S. African Americans, Haiti and Pan Americanism, 1870-1964. Gainesville: University Press of Florida.

Roberts, Neil. 2015. Freedom as Marronage. Chicago: University of Chicago Press.

Sarmiento, Domingo Faustino. 2004. Facundo: Civilization and Barbarism. Translated by Kathleen Ross. Los Angeles: University of California Press.

Starkey, James R. 1852. "Letter.” Frederick Douglass' Paper, May 27.

Turner, Jack. 2012. Awakening to Race: Individualism and Social Consciousness in America. Chicago: University of Chicago Press.

Wade, Peter. 1997. Race and Ethnicity in Latin America. London: Pluto Press.

Westerbeck, Colin L. 1999. "Frederick Douglass Chooses His Moment." Art Institute of Chicago Museum Studies 24 (2): $145-262$.

Wolin, Sheldon S. 1994. "Fugitive Democracy." Constellations 1 (1): $11-25$. 